\title{
Cadre Training in Managing Toddler Mother Classes in Kerta Payangan Village, Gianyar
}

\author{
Anak Agung Sri Agung Aryastuti ${ }^{*}$, Putu Nita Cahyawati ${ }^{2}$, Pande Ayu Naya Kasih \\ Permatananda ${ }^{3}$ \\ \{sriagungary@gmail.com\} \\ ${ }^{1,2,3}$ Faculty of Medicine and Health Sciences, Warmadewa University
}

\begin{abstract}
Kerta Village, Payangan Sub-district, is one of the regions in Gianyar Regency located in Bali with high stunting rate. Data obtained from village cadres and midwives through observations and short interviews, showed that in addition to stunting, several child health problems were also found such as lack of community knowledge on balanced nutrition, gadget addicts, exposure to cigarette smoking, and inappropriate parenting. Currently, Payangan Health Center which oversees the Kerta Payangan Village area has implemented various programs to support children's health, such as the mother and child health (KIA) program, one of which is manifested in the children's Integrated Healthcare Center services. In this village, a cadre of Toddler Family Development (BKB) was also formed and launched by the National Population and Family Planning Board (BKKBN). Although BKB cadres was formed in each Banjar, unfortunately it has not functioned optimally due to inadequate training related to children's health. Through this Community Service (PKM), BKB cadres were trained to design and manage a toddler mother class, which acts as a place for mothers to share and exchange health related experiences on toddler health. This research was carried out from August to September 2019 with a sample study of 37 participants from 8 Banjars in Kerta Village. The evaluated results showed that cadre knowledge on the toddler mother class increased after counseling. Participants are also trained to design it which is later applied independently in their respective work areas. Simulations and mentoring are conducted at the end of the activity to provide tangible experiences and increase participants' understanding. This activity is expected to increase the role of BKB cadres in improving toddlers health in Kerta Payangan Village, Gianyar.
\end{abstract}

Keywords: toddler mother class, cadre, toddler family development 


\section{Pendahuluan}

Agenda pembangunan global terdahulu yaitu Millenium Development Goals (MDGs) telah berakhir dan kini dilanjutkan dengan berpedoman pada agenda pembangunan global yang baru untuk periode 2016-2030 yaitu Sustainable Development Goals (SDGs). Dalam SDGs masalah kesehatan ibu dan anak masih menjadi salah satu prioritas masalah yang harus dituntaskan dan tertuang dalam tujuan No 3 SDGs. ${ }^{1}$

Masalah balita pendek (stunting) menjadi fokus perhatian dalam dunia kesehatan. Menurut UNICEF, 37\% anak - anak balita di Indonesia menderita gizi buruk dalam bentuk stunting, yang mana ini berarti 1 dari 3 anak di Indonesia menderita stunting. Kejadian stunting pada anak balita memerlukan perhatian khusus karena berkaitan dengan risiko penurunan kemampuan intelektual, produktivitas dan peningkatan risiko penyakit degeneratif di masa mendatang. ${ }^{2}$ Anak yang mengalami stunting cenderung menghadapi hambatan belajar di sekolah, berpenghasilan lebih rendah ketika dewasa dan cenderung mewariskan siklus kemiskinan antar generasi. ${ }^{3}$

Menurut WHO, Indonesia termasuk dalam kelompok negara berkembang dengan tingkat prevalensi stunting yang cukup tinggi yaitu sebesar 30,8\%, sedangkan WHO menargetkan angka stunting sebaiknya tidak lebih dari $20 \% .{ }^{4}$ Berdasarkan hasil Riset Kesehatan Dasar Provinsi Bali, Kabupaten Gianyar merupakan salah satu kabupaten di Bali dengan prevalensi stunting yang tinggi. Salah satu daerah dengan angka stunting yang tinggi adalah di Desa Kerta, Kecamatan Payangan, Kabupaten Gianyar. ${ }^{5}$ Dari hasil pelaksanaan post-graduate course (PGC) yang dilaksanakan oleh mahasiswa fase profesi Fakultas Kedokteran dan Ilmu Kesehatan (FKIK) Universitas Warmadewa pada Bulan Januari-Februari 2019 yang lalu, selain stunting ditemukan pula beberapa permasalahan kesehatan anak di Desa Kerta. Permasalahan-permasalahan tersebut antara lain kurangnya pengetahuan masyarakat mengenai gizi seimbang pada anak, gadget addict pada anak, paparan asam rokok pada anak, pola asuh yang kurang tepat, belum tersedianya ruang ramah anak, dan permasalahan perilaku hidup bersih. Saat ini puskesmas telah memiliki berbagai program untuk mendukung kesehatan anakanak. Program-program tersebut antara lain program kesehatan ibu dan anak (KIA) yang salah satunya diwujudkan dalam kegiatan layanan Posyandu anak-anak dan Kelas Ibu Balita. Program lainnya yang turut mendukung upaya peningkatan kesehatan anak yaitu program Bina Keluarga Balita (BKB) yang dicanangkan oleh Badan Kependudukan dan Keluarga Berecana Nasional (BKKBN). Program ini bertujuan untuk meningkatkan pengetahuan dan keterampilan orang tua dalam membina tumbuh kembang anak secara utuh dan optimal melalui pemberian stimulasi fisik, kognitif, sosioemosional dan spiritual. ${ }^{6,7}$

Di Desa Kerta, Payangan-Gianyar, telah dibentuk kader BKB di masing-masing Banjar. Kelompok kader tersebut telah terbentuk sejak awal tahun 2019. Namun kelompok kader di Desa Kerta belum berfungsi dengan optimal. Berdasarkan hasil wawancara dengan beberapa kader, bidan desa dan juga kepala desa, pengetahuan dan keterampilan yang dimiliki oleh para kader masih sangat minim. Pelatihan-pelatihan yang mereka dapatkan masih sangat sedikit mengingat bahwa kader-kader ini baru terbentuk di awal tahun 2019. Kegiatan-kegiatan yang dapat meningkatkan pengetahuan dan keterampilan kader BKB terkait dengan upaya pembinaan keluarga balita di desa tersebut masih sangat diperlukan.

Berdasarkan hasil wawancara lebih lanjut dengan beberapa kader di Desa tersebut dan bidan desa didapatkan beberapa kendala dalam pelaksanaan program-program di bidang kesehatan anak tersebut, antara lain: 
a. Minimalnya informasi yang didapatkan kader dan ibu rumah tangga yang memiliki balita mengenai kesehatan anak

b. Kader yang dalam hal ini sebagai perpanjangan tangan dari tenaga kesehatan di puskesmas tidak memiliki gambaran mengenai pelaksanaan program bina keluarga balita dan kelas ibu balita

c. Para kader dan ibu rumah tangga yang memiliki balita cenderung sibuk mengurus balita dan keluarganya. Mereka cenderung tidak sempat memperhatikan atau memeriksakan kesehatan balita mereka ke pusat pelayanan kesehatan terdekat sekalipun yang ada di dekat rumah mereka. Jika balita mengalami keluhan dalam kesehatan, mereka hanya datang ke bidan/perawat terdekat dan jarang ke pusat pelayanan kesehatan. Hal ini menyebabkan para ibu rumah tangga jarang sekali mengikuti penyuluhan atau sharing bersama-sama mengenai masalah kesehatan pada balita

d. Ceramah-ceramah atau penyuluhan terkait kesehatan ibu dan anak yang dilakukan di Desa Kerta kurang interaktif, cenderung bersifat satu arah. Aktivitas ini dirasakan kurang efektif karena informasi yang diberikan cenderung tidak bisa diserap secara maksimal

e. Kurangnya kemampuan kader dalam mengelola sebuah aktivitas yang lebih kreatif dan menarik agar partisipasi masyarakat menjadi lebih tinggi

Dari uraian masalah kesehatan prioritas yang dijabarkan pada bab sebelumnya,maka dapat diberikan solusi sebagai berikut:

a. Meningkatkan kemandirian keluarga dan masyarakat dalam memelihara dan merawat kesehatan ibu dan anak melalui penggunaan Buku KIA

b. Menginisiasi pelaksanaan kelas ibu balita (KIB) di masing-masing banjar di Desa Kerta dengan memberikan pengetahuan dan gambaran mengenai KIB. Kelas ibu balita adalah kelas dimana para ibu yang mempunyai anak berusia antara 0 sampai 5 tahun secara bersama-sama berdiskusi, tukar pendapat, tukar pengalaman akan pemenuhan pelayanan kesehatan, gizi dan stimulasi pertumbuhan dan perkembangannya dibimbing oleh fasilitator, dengan berpedoman pada buku KIA. Kelas ibu balita dirancang dengan metode belajar partisipatoris dimana para ibu tidak dipandang sebagai murid, melainkan sebagai warga belajar. Dalam prakteknya para ibu didorong untuk belajar dari pengalaman sesama, sementara fasilitator berperan sebagai pengarah kepada pengetahuan yang benar

c. Memberikan pelatihan bagi kader-kader BKB untuk merancang kelas ibu balita yang sesuai dengan kebutuhan dan kondisi di masing-masing Banjar. Pelatihan diberikan dalam bentuk penyampaian materi, identifikasi permaslahan kesehatan anak di masing-masing Banjar, penyusunan kurikulum kelas ibu balita, penyusunan rencana kerja dan jadwal pelaksanaan kelas ibu balita

d. Melakukan simulasi pelaksanaan kelas ibu balita sehingga para kader memiliki gambaran yang utuh mengenai pelaksanaan kelas ibu balita di masing-masing Banjar

Melalui kegiatan-kegiatan tersebut kader bina keluarga balita (BKB) dapat diberdayakan melalui pelaksanaan suatu kegiatan kelas ibu balita (KIB) yang bersifat kreatif dan partipatori sehingga partisipasi masyarakat dalam upaya menngoptimalkan tumbuh kembang anak dapat lebih ditingkatkan. ${ }^{8,9}$

\section{Metode Dan Pemecahan Masalah}

Kegiatan PkM dilaksanakan pada Bulan Agustus-September 2019 bertempat di Kantor Desa Kerta, Kecamatan Payangan, Kabupaten Gianyar. Persiapan dilakukan dengan 
melakukan koordinasi dan sosialisasi kegiatan meliputi pertemuan koordinasi dengan pihak Desa Kerta, Kecamatan Payangan, Kabupaten Gianyar serta bidan desa dan beberapa kader mengenai rencana pelaksanaan program ini. Pihak Desa, bidan dan kader dijelaskan mengenai tujuan, manfaat, alur kegiatan dan rencana monitoring/evaluasi kegiatan. Persiapan juga meliputi perencanaan tempat dan sarana dan prasarana yang diperlukan untuk pelaksanaan kegiatan. Metode yang digunakan dalam kegiatan ini adalah metode belajar aktif, yaitu para kader dilibatkan langsung dalam diskusi, praktek penyusunan kurikulum dan rancangan kelas ibu balita, serta bermain peran dalam simulasi pelaksanaan kelas ibu balita. Tahapan-tahapan pelaksanaan kegiatan meliputi:

a. Pre-test. Tahap ini dilakukan untuk mengetahui tingkat pengetahuan kader mengenai kelas ibu balita di awal kegiatan.

b. Pemaparan materi dan diskusi mengenai kelas ibu balita. Para kader diberikan pemaparan mengenai kelas ibu balita, tujuan aktivitas kelas ibu balita, metode pelaksanaannya, sarana dan prasarana yang diperlukan, metode evaluasinya, serta peranan kader dalam pelaksanaan kelas ibu balita tersebut

c. Praktek merancang kelas ibu balita. Pada tahap ini kader diperkenalkan cara merancang kelas ibu balita, dimulai dengan mengidentifikasi permasalahan yang ditemukan di masing-masing Banjar, penyusunan kurikulum kelas yang akan dilaksanakan, pemilihan narasumber dan fasilitator dalam kelas yang akan dilaksanakan, serta sarana dan prasarana yang diperlukan untuk pelaksanaan suatu kelas

d. Simulasi kelas ibu balita. Pada tahap ini para kader bermain peran dalam suatu rancangan simulasi kelas ibu balita yang dirancang untuk satu kali pertemuan

e. Post-test. Tahap ini dilakukan untuk mengetahui peningkatan pemahaman mengenai kelas ibu balita setelah diadakannya pelatihan pada kader

f. Evaluasi kegiatan. Evaluasi kegiatan dilakukan untuk mengetahui keberhasilan kegiatan ini dan keberlanjutan kegiatan ini di masing-masing Banjar.

\section{Hasil Kegiatan}

Kegiatan diawali dengan pengisian daftar hadir, pembagian materi dan silabus kegiatan, pembagian snack, dan penjelasan mengenai item-item kegiatan. Kegiatan dihadiri oleh kader Bina Keluarga Balita dari 8 Banjar di Desa Kerta, Payangan-Gianyar. Kegiatan juga dihadiri oleh kader posyandu, Bidan Desa, Pembina BKB, Kepala Desa beserta jajarannya. Kegiatan diawali dengan pemberian sambutan oleh Kepala Desa Kerta Payangan Kegiatan yang sekaligus dibuka secara resmi oleh Kepala Desa.

\subsection{Penyampaian materi mengenai tumbuh kembang anak}

Setelah dilakukan pre-test, kegiatan dilanjutkan dengan pemaparan materi mengenai tumbuh kembang anak. Pemaparan materi dilakukan selama 90 menit dengan metode dialog interaktif langsung. Mitra dibekali dengan materi mengenai tumbuh kembang anak dan buku KIA. Kegiatan ini berlangsung dengan sangat baik dan diikuti oleh seluruh mitra. Peserta mengikuti dengan antusias, hal ini terekam dalam banyaknya pertanyaan dan sanggahansanggahan yang muncul saat materi disajikan.

\subsection{Pelatihan merancang kelas ibu balita}


Perancangan kelas ibu balita dilaksanakan oleh kelompok mitra dari masing-masing Banjar. Salah satu rancangan kelas ibu balita yang berhasil disusun oleh mitra adalah sebagai berikut:

a. Identifikasi seluruh balita di wilayah kerja masing-masing

b. Pengelompokan balita sesuai dengan kelompok usia (0-1 tahun, 1-2 tahun, 2-5 tahun)

c. Setting waktu dan lokasi: di Balai Banjar setiap bulan sekali dengan waktu yang bersamaan dengan kegiatan Posyandu

d. Kebutuhan: buku panduan BKB dan Flipchart

e. Sarana/prasarana: kursi, meja, LCD dan laptop (jika memungkinkan), alat peraga edukatif (APE), alat tulis, materi yang disesuaikan dengan kebutuhan masing-masing kelompok

f. Tim kelas ibu hamil: fasilitator terlatih, narasumber, kader

\subsection{Simulasi kelas ibu balita}

Simulasi kelas ibu balita dilakukan dengan sharing mengenai optimalisasi perkembangan anak yang dipandu oleh seorang narasumber. Pemaparan diikuti dengan antusias oleh mitra yang diindikasikan dengan banyaknya pertanyaan yang muncul. Kegiatan diikuti dengan melakukan simulasi deteksi perkembangan anak yang dipandu oleh instruktur selama 30 menit. Deteksi perkembangan anak dilakukan dengan menggunakan kartu kembang anak yaitu alat sederhana berupa kartu untuk mendeteksi dini penyimpangan atau gangguan perkembangan anak usia 0-6 tahun.

\subsection{Post-test}

Di akhir kegiatan kembali diadakan post-test menggunakan kuesioner yang sama seperti post test di awal kegiatan. Dari pre-test dan post-test yang dilakukan, diketahui bahwa pengetahuan peserta tentang kelas ibu balita mengalami peningkatan.

\section{Kesimpulan}

Melalui kegiatan ini, pengetahuan dan keterampilan kader BKB dan kader Posyandu di Desa Kerta mengenai kelas ibu balita mengalami peningkatan. Peserta pelatihan telah mampu merancang kelas ibu balita yang nantinya dapat diterapkan di wilayah kerja masing-masing.

\section{References}

[1] UNDP. 2015. Konvergensi Agenda pembangunan nawa Cita, RPJMN, dan SDGs. Jakarta.

[2] Eka Kusuma, K., \& Nuryanto. (2013). Faktor Risiko Kejadian Stunting Pada Anak 2-3 Tahun (Studi di Kecamatan Semarang Timur). Journal of Nutririon College, 2(4), 523-530.

[3] UNICEF. (2013). Improving Child Nutrition The achievable imperative for global progress. New York. Retrieved from www.unicef.org/publications/index.html

[4] Kementerian Kesehatan Republik Indonesia. 2018. Hasil Utama Riskesdas 2018. Kemenkes RI Balitbangkes. Jakarta

[5] BPS (Badan Pusat Statistik). (2012). Statistik Daerah Kabupaten Gianyar 2012.

[6] Badan Kependudukan dan Keluarga Berencana Nasional (BKKBN). 2014. Strategi nasional Program Bina Keluarga Balita 2014-2025. Jakarta: BKKBN.

[7] Sustiarini C, Gamelia E, Hariyadi B. Analisis penggunaan Buku Kesehatan Ibu Anak. Kesmas. 2014:10 (1).14-20. 
[8] Kartikawati SL, Sutedja E, Dzulfikar. Pengaruh kelas ibu Balita terhadap peningkatan pengetahuan, sikap, dan perilaku Ibu Balita dalam merawat balita di Wilayah kerja Puskesmas Sukarasa Kota Bandung. Bhakti Kencana Medika. 2014; 1(4): 27-8.

[9] Susanti D, Wulandari H, Juaeriah R, Dewi SP. Penerapan Interprofessional Education (IPE) pada Kelas Ibu Balita oleh Mahasiswa Tenaga Kesehatan untuk Meningkatkan Sikap Ibu terhadap Kesehatan Balita di Kota Cimahi. JSK. 2017; 3(2): 51-57. 